\title{
RASIONAL DAN ELEMEN PERUBAHAN KURIKULUM 2013
}

\author{
Slameto \\ slameto_usw@yahoo.com \\ Pendidikan Guru Sekolah Dasar \& PPS-MP - FKIP - UKSW Salatiga
}

\begin{abstract}
ABSTRAK
Kurikulum 2013 merupakan pengembangan Kurikulum Berbasis Kompetensi yang telah dirintis pada tahun 2004 dan KTSP 2006. Para guru harus memiliki kesiapan yang memadai dan matang, mulai dari kesiapan dari segi kualifikasi, kompetensi serta juga siap dalam hal kesamaan pemahaman dan mindset (pola pikir) terhadap kurikulum baru tersebut. Proses pembelajaran yang mendorong siswa untuk aktif hanya mungkin terwujud bila mindset guru telah berubah, telah berjalan sesuai dengan arah dan perubahan Kurikulum 2013; Kegagalan mengubah mindset guru akan menjadi sumber kegagalan implementasi Kurikulum 2013. Persoalannya adalah bahwa perubahan mindset guru tidak bisa dilakukan dalam waktu singkat; Tulisan ini membahas 3 hal terkait dengan implementasi kurikulum 2013: rasional, eleman dan perlunya perubahan mindset guru dalam implementasinya.
\end{abstract}

Kata kunci: rasional, elemen perubahan Kurikulum 2013, mindset

\section{PENDAHULUAN}

Kurikulum 2013 merupakan pengembangan dari Kurikulum Berbasis Kompetensi yang telah dirintis pada tahun 2004 dan KTSP 2006. Menurut pihak Puskur dan Perbukuan Kemdikbud RI, fokus pengembangan kurikulum 2013 ini adalah mengurangi jumlah mata pelajaran, mengurangi materi pelajaran dan menambah jam pelajaran. Mengacu kepada Peraturan Pemerintah No. 32 Tahun 2013 tentang Standar Nasional Pendidikan, maka terdapat empat perubahan pada kurikulum baru ini, yaitu; 1). Perubahan pada Standar Kelulusan/SKL (Permendikbud no. 54 Tahun 2013), perubahan pada standar isi (Permendikbud no. 64 Tahun 2013), perubahan pada standar proses (Permendikbud no. 65 Tahun 2013) dan perubahan pada aspek penilaian (Permendikbud no. 66 Tahun 2013). Sementara empat standar lainnya tidak mengalami perubahan.

\section{PERUBAHAN KURIKULUM 2013}

\section{Rasional Perubahan Kurikulum 2013}

Pengembangan kurikulum perlu dilakukan karena adanya berbagai tantangan yang dihadapi, baik tantangan internal maupun tantangan eksternal. Tantangan internal antara lain terkait dengan kondisi pendidikan dikaitkan dengan 
tuntutan pendidikan yang mengacu kepada 8 (delapan) Standar Nasional Pendidikan yang meliputi standar pengelolaan, standar biaya, standar sarana prasarana, standar pendidik dan tenaga kependidikan, standar isi, standar proses, standar penilaian, dan standar kompetensi lulusan. Tantangan internal lainnya terkait dengan social akibat perkembangan penduduk Indonesia dilihat dari pertumbuhan penduduk usia produktif.

Terkait dengan tantangan internal pertama, berbagai kegiatan dilaksanakan untuk mengupayakan agar penyelenggaraan pendidikan dapat mencapai ke delapan standar yang telah ditetapkan. Di dalam Standar Pengelolaan hal-hal yang dikembangkan antara lain adalah Manajemen Berbasis Sekolah. Rehabilitasi gedung sekolah dan penyediaan laboratorium serta perpustakaan sekolah terus dilaksanakan agar setiap sekolah yang ada di Indonesia dapat mencapai Standar Sarana-Prasarana yang telah ditetapkan. Dalam mencapai Standar Pendidik dan Tenaga Kependidikan, berbagai upaya yang dilakukan antara lain adalah peningkatan kualifikasi dan sertifikasi guru, pembayaran tunjangan sertifikasi, serta uji kompetensi dan pengukuran kinerja guru. Standar Isi, Standar Proses, Standar Penilaian, dan Standar Kompetensi Lulusan adalah merupakan standar yang terkait dengan kurikulum yang perlu secara terus menerus dikaji agar peserta didik yang melalui proses pendidikan dapat memiliki kompetensi yang telah ditetapkan.

Terkait dengan perkembangan penduduk, saat ini jumlah penduduk Indonesia usia produktif (15-64 tahun) lebih banyak dari usia tidak produktif (anakanak berusia 0-14 tahun dan orang tua berusia 65 tahun ke atas). Jumlah penduduk usia produktif ini akan mencapai puncaknya pada tahun 2020-2035 pada saat angkanya mencapai 70\%. Ini berarti bahwa pada tahun 2020-2035 sumber daya manusia (SDM) Indonesia usia produktif akan melimpah. SDM yang melimpah ini apabila memiliki kompetensi dan keterampilan akan menjadi modal pembangunan yang luar biasa besarnya. Namun apabila tidak memiliki kompetensi dan keterampilan tentunya akan menjadi beban pembangunan. Oleh sebab itu tantangan besar yang dihadapi adalah bagaimana mengupayakan agar SDM usia produktif yang melimpah ini dapat ditransformasikan menjadi SDM yang memiliki kompetensi dan keterampilan melalui pendidikan agar tidak menjadi beban.

Tantangan eksternal yang dihadapi dunia pendidikan antara lain berkaitan dengan tantangan masa depan, kompetensi yang diperlukan di masa depan, persepsi masyarakat, perkembangan pengetahuan dan pedagogi, serta berbagai fenomena ocialt yang mengemuka. Tantangan masa depan antara lain terkait dengan arus globalisasi dan berbagai isu yang terkait dengan masalah lingkungan hidup, kemajuan teknologi dan informasi, kebangkitan industri kreatif dan budaya, dan perkembangan pendidikan di tingkat internasional. Di era globalisasi juga akan terjadi perubahan-perubahan yang cepat. Dunia akan semakin transparan, terasa sempit, dan seakan tanpa batas.Hubungan komunikasi, informasi, dan transportasi 
menjadikan satu sama lain menjadi dekat sebagai akibat dari revolusi industri dan hasil pengembangan ilmu pengetahuan dan teknologi. Arus globalisasi juga akan menggeser pola hidup masyarakat dari agraris dan perniagaan tradisional menjadi masyarakat industri dan perdagangan modern seperti dapat terlihat di WTO, ASEAN Community, APEC, dan AFTA. Tantangan masa depan juga terkait dengan pergeseran kekuatan ekonomi dunia, pengaruh dan imbas teknosains, serta mutu, investasi dan transformasi pada ocial pendidikan. Keikutsertaan Indonesia di dalam studi International TIMSS (Trends in International Mathematics and Science Study) dan PISA (Program for International Student Assessment) sejak tahun 1999 juga menunjukkan bahwa capaian anak-anak Indonesia tidak menggembirakan dalam beberapa kali laporan yang dikeluarkan TIMSS dan PISA yang hanya menduduki peringkat empat besar dari bawah. Penyebab capaian ini antara lain adalah karena banyaknya materi uji yang ditanyakan di TIMSS dan PISA tidak terdapat dalam kurikulum Indonesia.

Kompetensi masa depan yang diperlukan dalam menghadapi arus globalisasi antara lain berkaitan dengan kemampuan berkomunikasi, kemampuan berpikir jernih dan kritis, kemampuan mempertimbangkan segi moral suatu permasalahan, kemampuan menjadi warga negara yang bertanggungjawab, kemampuan mencoba untuk mengerti dan toleran terhadap pandangan yang berbeda, dan kemampuan hidup dalam masyarakat yang mengglobal.

Disamping itu generasi Indonesia juga harus memiliki minat luas dalam kehidupan, memiliki kesiapan untuk bekerja, memiliki kecerdasan sesuai dengan bakat/minatnya, dan memiliki rasa tanggung-jawab terhadap lingkungan. Dilihat dari persepsi masyarakat, pendidikan di Indonesia saat ini dinilai terlalu menitikberatkan pada aspek kognitif dan beban siswa dianggap terlalu berat. Selain itu pendidikan juga dinilai kurang bermuatan karakter. Penyelenggaraan pendidikan juga perlu memperhatikan perkembangan pengetahuan yang terkait dengan perkembangan neurologi dan psikologi serta perkembangan pedagogi yang terkait dengan observation-based (discovery) learning serta collaborative learning. Tantangan eksternal lainnya berupa fenomena ocialt yang mengemuka antara lain terkait dengan masalah perkelahian pelajar, masalah narkoba, korupsi, ocialtiv, kecurangan dalam ujian, dan gejolak social di masyarakat (social unrest).

\section{Perubahan Mindset}

Mindset atau pola pikir adalah asumsi, cara, atau notasi seseorang atau kelompok orang dalam menghargai atau menerima sesuatu hal sehingga dengan rela mengadopsinya atau menerimanya sebagai sesuatu pilihan. Fenomena ini kadangkadang disebut juga sebagai proses mental, pola pikir umum atau paradigma sehingga menjadi dasar pengambilan keputusan (Wikipedia). Inti dari fenomena ini ialah dapat menerima sesuatu sebagai sebuah pilihan. Mindset adalah pola pikir 


\section{Rasional dan Elemen Perubahan Kurikulum 2013 (Slameto)}

yang mempengaruhi pola kerja atau dalam ungkapan lain, mindset adalah sebuah sikap individu dimana singkronnya antara pola pikir/pengetahuan, keterampilan dan sikap prilaku. Orang yang memiliki hal tersebut, maka ia akan memiliki kesadaran/keikhlasan untuk menerima serta berkemauan untuk memperjuangkannya, dalam organisasi disebut dengan istilah budaya kerja.

Dinyatakan Carol Dweck (Wikipedia) bahwa pola pikir merupakan sumber kekuatan kemampuan seseorang. Mengenai kekuatan dibedakan dalam dua pandangan. Pertama menyatakan bahwa pola pikir itu tetap "pixed mindset" atau karakteristiknya dibawa sejak lahir. Pandangan kedua pola pikir dipandang sebagai sesuatu yang tumbuh - "growth mindset". Berdasarkan asumsi pertama keberhasilan seseorang ditentukan dengan kemampuannya yang dibawanya sejak lahir atau pixed mindset, sementara yang kedua menyatakan bahwa kekuatan datang pola pikir yang tumbuh. Kecerdasannya tumbuh karena pada dirinya berkembang pola pikir yang tumbuh - "growth mindset". Pertumbuhannya karena kerja keras, belajar, pelatihan serta ketabahannya.

Pola pikir melandasi tumbuhnya pola sikap seseorang. Pola sikap merupakan dasar pengembangan pola tindak. Dalam pengembangan pola sikap bersentuhan dengan emosi. Pembelajaran bersentuhan dengan perasaan, nilai-nilai, apresiasi, antusiasme, motivasi, dan sikap. Belajar tidak hanya memerlukan kecakapan berpikir, namun memerlukan hati. Jika hati tertutup, maka daya pikir pun tak dapat berkembang. Contoh dapat dilihat ketika orang marah, pikirannya tak dapat bekerja maksimal karena pikiran bekerja memerlukan ketenangan sikap. Salah satu elemen yang berubah dalam kurikulum 2013 adalah Standar Proses. Proses pembelajaran pada kurikulum 2013 ini diatur dengan Permendikbud nomor 65 tahun 2013 tentang Standar Proses Pendidikan Dasar dan Menengah, yang diubah dari Permendiknas No. 41 Tahun 2007. Standar Proses adalah kriteria mengenai pelaksanaan pembelajaran pada satuan pendidikan untuk mencapai Standar Kompetensi Lulusan. Standar proses mencakup perencanaan proses pembelajaran, pelaksanaan proses pembelajaran, penilaian hasil pembelajaran, dan pengawasan proses pembelajaran.

Mengacu kepada Permendikbud di atas, maka proses pembelajaran ke depan akan menggunakan pendekatan saintifik (scientific approach). Artinya Pembelajaran yang logic, berbasis pada fakta, data atau fenomena yang dapat dijelaskan dengan logika/penalaran tertentu; bukan sebatas kira-kira, khayalan, legenda, ataupun dongeng semata. Dengan pendekatan ini, maka penjelasan guru, respon siswa, dan interaksi edukatif guru-siswa terbebas dari prasangka yang sertamerta, pemikiran subjektif, atau penalaran yang menyimpang dari alur berpikir logis. Dengan pendekatan ini juga mendorong dan menginspirasi siswa berpikir secara kritis, analitis, dan tepat dalam mengidentifikasi, memahami, memecahkan masalah, dan mengaplikasikan materi pembelajaran. 
Berdasarkan Permendikbud Nomor 81A tahun 2013 tentang Implementasi Kurikulum 2013 dijelaskan bahwa langkah-langkah pembelajaran dengan menggunakan pendekatan ilmiah ini ada lima. Diawali dengan mengamati, kemudian menanya, mengumpulkan informasi/mencoba, menalar/menghubunghubungkan dan mengkomunikasikan. Mencermati lima langkah pembelajaran beserta aktifitas pembelajarannya, maka dibutuhkan perubahan mindset dan komitmen kuat dari para pendidik dalam menerapkannya. Merubah kebiasaan mengajar dengan pola lama yang sudah berurat berakar seperti berceramah (transfer of knowladge) kepada pola dan strategi baru yang lebih banyak mengajar siswa mencari tahu sendiri akan sesuatu. Menurut Jamal Ma'mur Asmani, guru ideal itu adalah guru-guru yang kreatif, tidak pernah merasa cukup dan puas, selalu berupaya mencari yang baru dalam pembelajarannya.

Mendikbud dalam pidatonya saat launching kurikulum baru tahun 2013, mengingatkan bahwa dalam penerapan langkah-langkah pembelajar-an scientific ini guru/ tenaga pendidik harus hati-hati agar membiasakan anak didiknya untuk mengamati, membiasakan untuk bertanya, membiasakan untuk melakukan eksperimen, membiasakan untuk nalar dan mengkomnikasikan. Demikian kutipan dari penjelasan Mendikbud, hal tersebut dilakukan oleh semua guru, apapun mata pelajarannya. Jelas sekali di sini bahwa mendikbud ingin memberi stessing kepada para guru agar selalu berhati-hati jangan sampai lupa bahwa proses pembelajaran pada kurikulum 2013 ini menggunakan lima langkah pembelajaran.

Pendidikan yang sesuai dengan kebutuhan masa depan (tuntutan kurikulum 2013) hanya akan dapat terwujud apabila terjadi pergeseran mindset atau perubahan pola pikir. Pergeseran itu meliputi proses pembelajaran sebagai berikut. a). Dari berpusat pada guru menuju berpusat pada siswa. b). Dari satu arah menuju interaktif. c). Dari isolasi menuju lingkungan jejaring. d). Dari pasif menuju aktifmenyelidiki. e). Dari maya/ abstrak menuju konteks dunia nyata. f). Dari pembelajaran pribadi menuju pembelajaran berbasis tim. g). Dari luas menuju perilaku khas memberdayakan kaidah keterikatan. h). Dari stimulasi rasa tunggal menuju stimulasi ke segala penjuru. i). Dari alat tunggal menuju alat multimedia. J). Dari hubungan satu arah bergeser menuju kooperatif. k). Dari produksi massa menuju kebutuhan pelanggan. 1). Dari usaha sadar tunggal menuju jamak. m). Dari satu ilmu pengetahuan bergeser menuju pengetahuan disiplin jamak. n). Dari kontrol terpusat menuju otonomi dan kepercayaan. o). Dari pemikiran faktual menuju kritis. p). Dari penyampaian pengetahuan menuju pertukaran pengetahuan.

Selain perubahan pada standar proses, elemen lain yang mengalami perubahan dalam kurikulum 2013 adalah Standar Penilaian. Penilaian pembelajaran pada kurikulum 2013 ini diatur dengan Permendikbud nomor 66 tahun 2013 tentang Standar Penilaian, yang diubah dari Permendiknas No. 20 Tahun 2007. Mengacu kepada Permendikbud di atas, maka standar penilain pembelajaran ke depan akan 


\section{Rasional dan Elemen Perubahan Kurikulum 2013 (Slameto)}

menggunakan penilain otentik (authentic assessment). Artinya 1). penilaian proses dan hasil pembelajaran. 2). Sinonim dari kata asli, nyata, valid, atau reliabel. 3). Suatu penilaian pembelajaran yang merujuk pada situasi atau konteks "dunia nyata". 4). Mengukur, memonitor dan menilai semua aspek hasil belajar, baik yang tampak sebagai hasil akhir dari suatu proses pembelajaran, maupun berupa perubahan dan perkembangan aktivitas, dan perolehan belajar selama proses pembelajaran didalam kelas maupun diluar kelas.

Penilaian otentik adalah penilaian yang secara langsung bermakna, dalam arti bahwa yang dinilai memang demikian yang sesungguhnya terjadi dan dapat terjadi dalam kehidupan sehari-hari. Jadi penilaian otentik menilai kemampuan riil siswa dalam kaitannya dengan kehidupan sehari-hari. Penilaian otentik merupakan proses pengamatan, perekaman, pendokumentasian karya (apa yang dilakukan anak dan bagaimana hal itu dilakukan) sebagai dasar penentuan keputusan yang dapat menuju pada pembentukan anak mandiri.

Penegasan ke depan bahwa para guru harus merubah pola pikir (mindsetnya) dalam menilai pembelajaran, sebab dalam kurikulum baru ini mesti ada tiga syarat utama sebuah penilaian bisa dilaksanakan, pertama, jelas objek yang akan dinilai, kedua, jelas pula teknik penilain/instrumennya dan ketiga, ada rubrik (pedoman) penilaiannya dan cara pemberian skornya. Proses penilaian yg dilaksanakan dulu secara tradisional dan bahkan sampai sekarang adalah penilaian terhadap out put (hasil) semata. Guru mengajar, murid belajar dan nanti menilai. Sedangkan sekarang, tak obahnya seperti jalinan pita yang sangat kokoh dan berpadu. Artinya, antara mengajar, belajar dan menilai berlangsung sejak dari proses sampai kepada hasilnya. Dengan konsep penilaian seperti ini akan merepotkan guru, sebab selain mengajar, guru juga bertugas menilai anak didiknya dalam waktu yang bersamaan. Di samping itu, bahwa penilaian otentik (asli, nyata, valid dan reliabel), harus dilengkapi dengan tiga perangkat penilaian yang sesungguhnya, yakni; objek yang akan dinilai, teknik/instrumen penilaian dan rubriknya. Kebiasan guru yang mungkin dahulu hanya menilai hasil saja serta belum menggunakan kriteria-kriteria yang jelas perlu diselaraskan dengan pola penilaian yang baru ini.

\section{Elemen Perubahan Kurikulum 2013}

Ternyata di dalam kurikulum 2013 hanya ada 4 elemen perubahan yang mendasar yaitu Standar Kompetensi Lulusan (SKL), Standar Proses, Standar Isi, dan Standar Penilaian. Untuk elemen SKL, semua jenjang pendidikan mulai dari SD sampai dengan SMA/SMK menuntut adanya peningkatan dan keseimbangan soft skill dan hard skill yang meliputi aspek kompetensi sikap (afektif, attitude), ketrampilan (psikomotor), dan pengetahuan (kognitif).

Upaya mewujudkan tujuan pendidikan nasional diperlukan profil kualifikasi kemampuan lulusan yang dituangkan dalam standar kompetensi lulusan. Dalam 
penjelasan Pasal 35 Undang-Undang Nomor 20 Tahun 2003 disebutkan bahwa standar kompetensi lulusan merupakan kualifikasi kemampuan lulusan yang mencakup sikap, pengetahuan, dan keterampilan peserta didik yang harus dipenuhinya atau dicapainya dari suatu satuan pendidikan pada jenjang pendidikan dasar dan menengah.

Standar Kompetensi Lulusan digunakan sebagai acuan utama pengembangan standar isi, standar proses, standar penilaian pendidikan, standar pendidik dan tenaga kependidikan, standar sarana dan prasarana, standar pengelolaan, dan standar pembiayaan.

a. Dimensi sikap

Memiliki perilaku yang mencerminkan sikap orang beriman, berakhlak mulia, berilmu, percaya diri, dan bertanggung jawab dalam berinteraksi secara efektif dengan lingkungan social dan alam di lingkungan rumah, sekolah, dan tempat bermain.

b. Dimensi Pengetahuan

Memiliki pengetahuan social dan konseptual berdasarkan rasa ingin tahunya tentang ilmu pengetahuan, teknologi, seni, dan budaya dalam wawasan kemanusiaan, kebangsaan, kenegaraan, dan peradaban terkait fenomena dan kejadian di lingkungan rumah, sekolah, dan tempat bermain.

c. Dimensi Keterampilan

Memiliki kemampuan social dan tindak yang produktif dan kreatif dalam ranah abstrak dan konkret sesuai.

Kompetensi Inti merupakan terjemahan atau operasionalisasi SKL dalam bentuk kualitas yang harus dimiliki mereka yang telah menyelesaikan pendidikan pada satuan pendidikan tertentu atau jenjang pendidikan tertentu, gambaran mengenai kompetensi utama yang dikelompokkan ke dalam aspek sikap, pengetahuan, dan keterampilan (afektif, kognitif, dan psikomotor) yang harus dipelajari peserta didik untuk suatu jenjang sekolah, kelas dan mata pelajaran. Kompetensi Inti harus menggambarkan kualitas yang seimbang antara pencapaian hard skills dan soft skills.

Kompetensi Inti berfungsi sebagai social pengorganisasi (ocialtiv element) kompetensi dasar. Sebagai social pengorganisasi, Kompetensi Inti merupakan pengikat untuk organisasi sosial dan organisasi horizontal Kompetensi Dasar. Organisasi sosial Kompetensi Dasar adalah keterkaitan antara konten Kompetensi Dasar satu kelas atau jenjang pendidikan ke kelas/jenjang di atasnya sehingga memenuhi prinsip belajar yaitu terjadi suatu akumulasi yang berkesinambungan antara konten yang dipelajari siswa. Organisasi horizontal adalah keterkaitan antara konten Kompetensi Dasar satu mata pelajaran dengan konten Kompetensi Dasar dari mata pelajaran yang berbeda dalam satu pertemuan mingguan dan kelas yang sama sehingga terjadi proses saling memperkuat. 


\section{Rasional dan Elemen Perubahan Kurikulum 2013 (Slameto)}

Kompetensi Inti dirancang dalam empat kelompok yang saling terkait yaitu berkenaan dengan sikap keagamaan (kompetensi inti 1), sikap social (kompetensi 2), pengetahuan (kompetensi inti 3), dan penerapan pengetahuan (kompetensi 4). Keempat kelompok itu menjadi acuan dari Kompetensi Dasar dan harus dikembangkan dalam setiap peristiwa pembelajaran secara social ative. Kompetensi yang berkenaan dengan sikap keagamaan dan social dikembangkan secara tidak langsung (indirect teaching) yaitu pada waktu peserta didik belajar tentang pengetahuan (kompetensi kelompok 3) dan penerapan pengetahuan (kompetensi Inti kelompok 4).

Untuk elemen Standar Isi, kedudukan mata pelajaran kompetensi yang semula diturunkan dari mata pelajaran berubah menjadi mata pelajaran dikembangkan dari kompetensi. Untuk pendekatan yang dilakukan adalah: jenjang SD tematik terpadu dalam semua mata pelajaran, jenjang SMP kompetensi dikembangkan melalui mata pelajaran.

Untuk elemen Standar Proses, bahwa semua siswa (mulai SD s.d. SMA/SMK) harus memiliki kemampuan untuk mengamati, menanya, mengolah, menyajikan, menyimpulkan, bahkan sampai mencipta. Belajar tidak hanya terjadi di dalam kelas, tapi juga boleh di luar kelas seperti perpustakaan, bengkel sekolah, industri/instansi terkait, dan bahkan masyarakat sekitar. Guru bukan satu-satunya sumber belajar, tapi juga dapat diperoleh dari buku, ocia, TV, radio, internet. Dan sikap (attitude) tidak diajarkan secara verbal, tetapi siswa akan lebih banyak melihat dari apa yang dicontohkan oleh guru dengan memberikan suri tauladan yang baik.

Untuk elemen Standar Penilaian, jika biasanya nilai diambil dari sebuah tes/ujian maka diubah menjadi penilaian yang otentik (mengukur semua kompetensi mulai dari sikap, ketrampilan, dan pengetahuan berdasarkan proses dan hasil kerja. Setiap siswa memiliki semua rekaman kegiatan berupa portofolio yang dibuat oleh siswa sendiri sebagai socialtiv utama penilaian. Ekstrakurikuler Pramuka akan menjadi wajib pada semua jenjang pendidikan dasar sampai menengah.

\section{PENUTUP}

Meskipun perubahan kurikulum sudah merupakan sebuah keniscayaan, akan tetapi perlu adanya pra kondisi yang harus dan bahkan wajib dipenuhi, terutama terkait dengan kesiapan para guru selaku garda terdepan dalam proses implementasinya. Sebagai ujung tombak keberhasilan reformasi kurikulum, guru perlu memiliki kesiapan yang memadai, mulai dari kesiapan dari segi kualifikasi, kompetensi serta juga siap dalam hal kesamaan pemahaman dan/mindset (pola pikir) terhadap kurikulum baru tersebut. Tulisan ini telah berupaya menjelaskan sekilas tentang kurikulum tahun 2013 dan perubahan-perubahannya serta 
pentingnya perubahan mindset guru. Bagaimana pula pentingnya perubahan mindset yang harus terjadi dalam proses pembelajaran dan evaluasinya.

\section{DAFTAR PUSTAKA}

Holis, Gus. 2013. Kurikulum 2013 | KI-KD Untuk SD/MI dan SMP/ MTs. http://guraru.org/guru-berbagi/kurikulum-2013-sk-kd-untuk-sdmi-dansmpmts/ (21 November 2014)

Jejaring Indonesia. 2013. Elemen Perubahan Kurikulum 2013. http:// www.jejaring.web.id/elemen-perubahan-kurikulum-2013-bagian-1/ (21 November 2014)

Mahanani. 2013. Rasional Pengembangan Kurikulum 2013. http://www.medukasi.web.id/ 2013/06/rasional-pengembangan-kurikulum-2013.html (20 November 2014).

Sriyono, Iman. 2013. Perubahan Mindset Dalam Kurikulum 2013 http:// www.slideshare.net/ imansriyono/ perubahan-mindset (21 November 2014)

Wikipedia, Mindset. http://en.wikipedia.org/wiki/Mindset. (21 November 2014) 